発表の際は明示してもらいたい.

○FCRの発表には，画像処理条件が独自の表現があり， 一般的に理解しにくいので，なにか改善策はないもの か？(宮崎 稻津) 等が要望された。

FCR の画像処理では, 周波数, 階調曲線等一般的表現 が可能なものは，できるだけ理解できるような表現にす べきであろう. 現在処理条件は, 各施設での至適条件設 定が行われている. 今後, 臨床例が増加することで, 適 応範囲の検討や，アーチファクト等についての報告をも 発表されることを期待したい。

テシタルサフトラクション

\section{DSA 装露の特性曲線の測定}

\section{座長 松尾英典（長崎大学病院）}

熊本大学医療短大
O東田善治・松本政典
熊本大学病院中放部
洞田貫誠志・園田良男・守部伸幸
平田幸徳・松下元一・勝田 昇
肥合康弘

〔目的〕DSA 装置の特性曲線の測定と, 特性曲線に影 響を与える因子の検討を行った。特性曲線に影響を与え る因子として，マトリックスサイス，線質，I.I. サイス， カメラの絞り, veiling glare および散乱線などの影響に ついて検討した。

〔方法〕特性曲線の測定法として，アルミステップ法， X線強度法の 2 つを用いた。

〔結論〕1.特性曲線の形は，X線々質，I.I.サイズ よびカメラの絞りによって影響を受けない。

2. 特性曲線の形は, 用いるマトリックスサイズ, 散乱 線および veiling glareによって変化する。

3. 2 つの測定法で測定した特性曲線の形は一致する.

13. Contrast-Detail (C-D) ファントムによる DSA 装 置の評価

\section{熊本大学医学部附属病院中央放射線部 ○洞田貫誡志・松下元一・園田良男 守部伸幸・平田幸德・勝田 昇 肥合康弘 \\ 熊本大学医療技術短期大学部 東田菩治・松本政典}

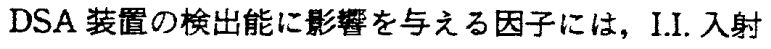
線量, マトリックスサイスおよびI.I.サイスなどがある。 今回われわれは, Contrast-Detail (C-D)ファントムを 製作し，DSA 装置の楛出能について模討した。

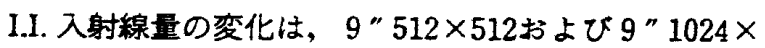

1024とも線量が増加するにしたがい検出能は良くなる。 マトリックスサイズによる比較は，同一線量レベルで は512マトリックスが良く,1ピクセル当りの線量を同じ にすれば，架間分解能にすぐれた1024マトリックスが良 くなる. 9"と7”の比較は, 同一線量レベルではほとん ど変わらず, 1 ピクセル当りの線量を同等にすれば, 空 間分解能にすぐれた 7 "が良い結果であった。

\section{4.ファントムによる DSA 跲置の基本特性の評価 熊本大学医学部附属病院中央放射線部 \\ ○勝田 昇・松下元一・森田勝行 洞田貫誠志・守部伸幸・肥合康弘 熊本大学医療技術短期大学部 東田善治・松本政典}

DSA 畒の日常の品筫管理を目的として製作された Nuclear Associates 社製 DSA 用ファントム76-700を購 入し，本学に設置されているDSA 置（日立 DFA-II） のコントラストレンジ, 解像力, 低コントラスト血管像 の検出能および直線性などの基本的な特性を測定した。 結果は,コントラスト曲線（アクリル厚に対するDSA 値）は，マトリックスサイズ $(512 \times 512,1024 \times 1024)$ によって異なり, 散乱線の寄与が小さい条件下では, DSA 值の高い所と低い所で飽和する傾向がある.キャー トによる解像限界は1024マトリックスの方が高いが，低 コントラスト血管像の検出能は512,1024ともほとんど差 は見られなかった。

\section{DSA の画墓改萻に関する検討}

\section{佐賀医科大学附属病院放射線部}

○成末彰博・阿部一之・角南克己

(目的) 3 モードタイプI.I.によるDSAの画筫改善 を画像処理機能拡充, フィルタリング, 処理モードを含 む脳血管 IVDSA を中心に画質改善を行ったので報告す る.

〔結果〕硬質塩化ビニールの物理データから頭部用フ イルタを作成して画質向上した，9インチ，6インチ， CI, PI モード別に I.I. 久射線量率，コントラスト，ノイ ス測定を行いPIの方が有用である。臨床評価でもPIモ ードの方が線量不足の目立たない画質が得られている。 また各インチサイズ別の鉛マスクの作成，フィルタ 2 段 トレイ化, 取込み条件の整備等, PI モードでの画質向上 を検討している。

\section{座長集約}

今回 DSA セクションでは，4題が提出され，その基本 特性，ならびにフィルタ効果における画筫改善の報告が なされた.DSA の評価で留意して置かねばならないこと 